corrections

\title{
Mitotic recombination effects homozygosity for NF1 germline mutations in neurofibromas
}

E. Serra, T. Rosenbaum, M. Nadal, U. Winner, E. Ars, X. Estivill \& C. Lázaro

Nature Genet. 28, 294-296 (2001).

The germline mutation of patient MASG indicated in Fig. $1 d$ should be IVS22 $+1 \mathrm{G} \rightarrow \mathrm{C}$, rather than IVS22+1C $\rightarrow \mathrm{G}$.

\section{Human mitochondrial DNA deletions associated with mutations in the gene encoding} Twinkle, a phage $\mathrm{T7}$ gene 4-like protein localized in mitochondria

J.N. Spelbrink, F.-Y. Li, V. Tiranti, K. Nikali, Q.-P. Yuan, M. Tariq, S. Wanrooij, N. Garrido, G. Comi, L. Morandi, L. Santoro, A. Toscano, G.-M. Fabrizi, H. Somer, R. Croxen, D. Beeson, J. Poulton, A. Suomalainen, H.T. Jacobs, M. Zeviani \& C. Larsson

Nature Genet. 28, 223-231 (2001).

The affiliation for G. Comi is Centro Dino Ferrari, Institute of Clinical Neurology, University of Milano, I.R.C.C.S. Ospedale Maggiore Policlinico, Milano, Italy.

erratum

Promoter-specific binding of Rap1 revealed by genome-wide maps of protein-DNA association

J.D. Lieb, X. Liu, D. Botstein \& P.O. Brown

Nature Genet. 28, 327-334 (2001).

An error was introduced while preparing the paper for the press. It occurs in the first sentence of the fourth full paragraph of page 332 . The sentence "A preference for binding to intergenic regions, and more particularly to potential promoters, may be a general property of proteins that act at promoters but recognize DNA motifs that are found throughout the genome" should conclude: “...act as promoters but recognize DNA motifs that are found throughout the genome." 